\section{Palæochemistry of the Ocean}

A QUANTITATIVE account of oceanic palæochemistry depends largely on the theory accepted for the origin of the ocean, especially for its halogen content. Yet with any'tenable view, useful limits for biological consideration can be established for such quantities as the total salinity at the beginning of the Cambrian period. The $\mathrm{K} / \mathrm{Na}$ ratio of the original ocean can also be stated with some confidence, when we consider that the mean composition of igneous rock has not appreciably changed over the oceanic age.

The original $K / N a$ ratio of the ocean. The speculations of Macallum ${ }^{1}$ on the origins of the cellular potassium, and the vogue they have obtained, makes this question of some interest to the biologist. According to Macallum, potassium was more concentrated than sodium in the primitive ocean (the $K / \mathrm{Na}$ ratio being about $2 \cdot 0$ ) and the cell to-day with more potassium than sodium tends to repeat in an altered environment a primitive adaptation. As evidence for the higher potassium concentration he cites analyses of Reindeer Lake and Churchill River ${ }^{2}$ situated in the zone of Archæan rock in Canada. Against this there is the Ottawa River $^{3}$, in a region of similar rock with a $\mathrm{K} / \mathrm{Na}$ ratio less than unity $(0 \cdot 64)$. The Hayes and Nelson Rivers ${ }^{4}$, draining wide areas of Archæan as well as later sedimentary strata, have a $\mathrm{K} / \mathrm{Na}$ ratio of 0.32 and 0.16 , which are less than the total river average of $0.37^{5}$; and the Mahanuddy, which in India drains a wide area of Arch an rock, has a $\mathrm{K} / \mathrm{Na}$ ratio of only $0 \cdot 28^{6}$.

Occasionally, high $\mathrm{K} / \mathrm{Na}$ ratios may be found in rivers and lakes not associated with crystalline or Archæan rock, for example, in the Würmsee and Königsee $^{7}$ (Macallum cites such as evidence for his view when it is clearly against it); and the potash lakes of Nebraska ${ }^{8}$ occur, too, in regions where there is no outcropping of igneous or Archæan formations.

At the same time there is no apparent reason why potassium should be higher than sodium in the early seas, since the $\mathrm{K} / \mathrm{Na}$ ratio in igneous rock is 0.92 , and whether we consider the action of neutral or very weakly acidic rain, or of hydrochloric acid, potassium is not more readily dissolved from the rock than sodium. It is dissolved less readily. This may be proved from Merrill's studies' ${ }^{9}$ of rock weathering, from the mean analyses of rivers draining igneous rock, and from Taylor's laboratory experiments ${ }^{10}$ with hydrochloric acid.

Occasional high $\mathrm{K} / \mathrm{Na}$ values are simply explained by a local preponderance in the rock of potassium compounds such as orthoclase, leucite, or biotite.

Oceanic salinity at the beginning of the Cambrian period. Whether we suppose the oceanic chloride to have been present almost entirely in the original atmosphere of a cooling earth, or to have originated as meteoritic chloride of iron, or again to have condensed along with the water of the ocean from volcanic emissions, the total ionic content will not change greatly, if at all, from its value at the outset. Only on one theory of the origin of the ocean, in which the chloride, but not the water, has been entirely supplied from volcanoes, does it alter from something like lake water to its present composition.

With such a theory and a consideration of the relevant data it may be shown that the salinity at the beginning of the Cambrian age was about $1 \cdot 6-2 \cdot 0$ per cent. In this estimate account is taken of the changing relation of igneous to sedimentary surface, of the different proportions of sodium to sediment in water draining igneous and sedimentary rock; and it is also assumed that the total depth of the pre-Cambian strata is 40 per cent of the whole sedimentary depth, which would appear to represent approximately the current view. Even if we reduced the figure to 25 per cent the salinity at the beginning of the Cambrian period would still be $1 \cdot 2-1 \cdot 6$ per cent. Equating, therefore, the salinity of mammalian blood (about 0.9 per cent) with that of the Cambrian ocean, in which Protovertebrates may have first appeared, is a speculation not supported by the geochemical data. This, however, does not militate against the view that the ratios of the inorganic ion concentrations in mammalian plasma may have broadly an oceanic significance (Bunge ${ }^{11}$; Quinton ${ }^{12}$ ).

A more detailed consideration of such questions will be submitted to the Royal Irish Academy.

University College, E. J. CONWAY. Dublin.

March 7.

1 Macallum, A. B., Physiol. Rev., 6, 316 (1926).

${ }^{2}$ Adams, F. D., Report Geol. Survey of Canada, 9 C. (1878); Report Geol. Survey of Canada, $6 \mathrm{H}$. (1880-82).

${ }^{3}$ Report Geol. Survey of Canada, 565 (1863).

- Dittmar, W., Report Geol. Survey of Canada, 77 C. (1879-80).

"Clarke, F. W., "Data of Geochemistry", Bull. 770 U.S. Geol. Survey, 119 (1924).

' Nicholson, E., J. Chem. Soc., 26, 229 (1873).

" Clarke, F. W., "Data of Geochemistry", Bull. 770, U.S. Geol. Survey, $100(1924)$

8 Erickson, E. T., Bull. U.S. Geol. Survey, No. 715, 133 (1921).

"Merrill, G. P., "Rocks, Rock Weathering and Soils". (Macmillan, 1897).

${ }^{20}$ Taylor, R. I., Proc. Manchester Lit. and Phil. Soc., 50, 9 (1905-6).

1 Bunge, G., "Lehrbuch der physiologischen und pathologischen Chemie"', Leipzig (1889).

12 Quinton, B., C.R. de la Soc, de Biol., 935 (1897).

\section{Control of the Kromnek (Spotted Wilt) Disease of Tomatoes}

IN many seasons the kromnek disease causes heavy losses in both tobacco and tomato in the Cape Province and Transvaal. Its virus origin was first diagnosed $^{1}$ in the Kat River area of the eastern Cape Province, and it has since been identified with the spotted wilt disease now well known in many parts of the world. In the Kat River area it is transmitted mainly, if not entirely, by the feeding of a thrips (Frankliniella schultzei Trybom) which has a wide host range among both wild and cultivated plants. ${ }^{2}$ The virus likewise attacks a very great variety of plants ${ }^{3}$ and the control of the disease is therefore a very difficult problem which has not so far been solved for South Africa.

Tartar emetic is used effectively against the citrus thrips in America, and preliminary trials with it at this laboratory have given very promising results with regard to the control of kromnek in tomatoes. The formula used was the same as that advised for citrus thrips, namely, $1 \mathrm{lb}$. tartar emetic plus $2 \mathrm{lb}$. sugar to 100 gallons of water. Spraying was started in the outdoor seed-bed in October when the seedlings were still in the cotyledonary stage and were already being attacked by the disease vector; it was repeated frequently during the subsequent nine weeks. Control beds a few yards away were left unsprayed; 